\title{
Highway Costs and Efficient Mix of State and Local Funds
}

\author{
David Levinson and Bhanu Yerra
}

Governments and transportation networks are both hierarchically organized. Some state governments finance most of their highways, whereas in other states similar roads are financed locally. Larger governments attain scale economies. However, they also tend to be more bureaucratic and have higher operating costs, all else being equal, because of problems such as span of control. A study was done to relate highway expenditures with the share of expenditure by state governments to determine how governments should allocate expenditure on all roads in a state. Highways are divided into two hierarchical classes (higher and lower), governments into two layers (state and local), and costs into capital and operations and maintenance. Regression models to predict different highway expenditures on each highway class as a function of utilization, capacity, and funding shares are estimated. It is found that there is a share of expenditures by each level of government for each highway class that results in a minimum expenditure for each funding category (capital and operations). That minimum is not very far from typical state and local mixes found in many states. The results can be applied in formulation of efficient network financing arrangements. Policies can be formulated that would help adjust the financial responsibilities of transportation networks between government layers.

States are continually considering returning some roads to localities while assuming responsibility for other local roads, so determining what level of government should be responsible for provision, finance, operation, and regulation of each highway class is an important issue. Management of a highway class by a geographically too small or too large jurisdiction brings about extra costs that can be avoided by appropriately assigning government layers to a roadway class. The objective of this study is to find the share of costs borne by each government layer for each highway class that minimizes expenditures.

Both highways and government are hierarchically arranged. Highways are classified into hierarchies depending on the amount of through movement and land access they provide (1). The shape and slope of the hierarchical pyramid of highways depend on the length or number of highways in a state that falls into each class. Government is classified into hierarchical layers depending on the area administered under its jurisdiction.

Each class of highway is controlled or financed by a set of government layers. A new dimension can be added to this problem if different costs, shared by a set of government layers, are considered. With this cost dimension, the hierarchical pyramid of highways is represented in Figure 1. Each block in Figure 1 represents dollars invested (or expenditure share) by a government layer in a highway class for a particular purpose such as maintenance or capital outlay.

Department of Civil Engineering, University of Minnesota, 500 Pillsbury Drive SE, Minneapolis, MN 55455.
If a government layer is not funding certain cost categories of a highway class, that block in Figure 1 is zero.

Government layers associated with a highway class can share costs in different proportions to reach a minimum. Figure 2 shows the variation of cost with respect to share of expenditure following a parabolic form. If significant economies of scale exist, the optimal expenditure is near to $100 \%$ state-funded, but if there are large diseconomies, for instance, management costs and span of control issues, the optimal share moves to the left in Figure 2. Only two types of government levels are considered in this study: state and local. Federal dollars are channeled through states and so are combined with state dollars here. The share of expenditure by a government layer is considered a variable in the model, allowing the attainment of an optimal combination that minimizes highway expenditures.

Capital outlay and maintenance costs are also differentiated. Capital outlays are associated with highway improvements, including land acquisition and other right-of-way costs; preliminary and construction engineering; construction and reconstruction; resurfacing, rehabilitation, and restoration costs of roadway and structure; and installation of traffic service facilities such as guardrails, fencing, signs, and signals (2). Maintenance costs, or investments in existing highways, are required to keep highways in usable condition. Total cost is defined as the sum of capital outlay and maintenance costs, thereby excluding administration and miscellaneous, highway law enforcement and safety, interest, and bond retirement costs.

The FHWA Highway Statistics series defines 12 roadway classes, which are grouped here into higher and lower classes. The higher class consists of Interstates, principal arterials, and minor arterials. The lower class consists of major collectors, minor collectors, and local roads. An all-roads case is also considered in modeling.

Expenditure on a highway depends on that road's output, network extent, and prices of inputs. Since determining optimal expenditure shares by associated government layers is the objective of this study, expenditure share is an important variable in the model and is introduced in quadratic form. Different output variables on which highway expenditure depends are vehicle miles traveled (VMT) by passenger cars, trucks, and other vehicles. A few network variables are length of highways, average width of highways, average number of lanes, average thickness of the pavement, and so on.

Previous studies (3) that included prices of capital, labor, and construction materials as independent variables found that although prices of construction materials were not significant, interest rates and labor costs were significant factors in the long run but insignificant in the short run. However, it has not been possible to successfully estimate a model with prices, output, and network extent simultaneously. 


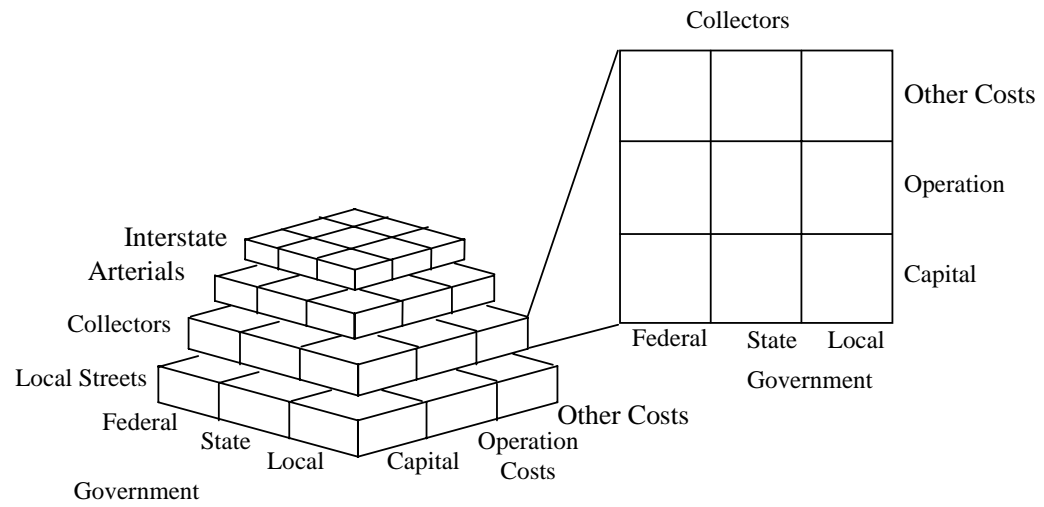

FIGURE 1 Schematic representation of three-dimensional structure of highways, highway costs, and government layers.

\section{DATA}

The data required for the analysis were obtained from the U.S. Department of Transportation for 1996 (2).

This model requires capital outlay and maintenance costs for higher and lower road classes by state and local governments. The flow of money between state and local governments by cost and highway class is shown in Figure 3. Local government is assumed to be investing directly on lower-class roads only. But payments from local to state government are in turn invested on both higher- and lower-class roads. Therefore, local government is indirectly investing in higherclass roads. Similarly state government aid to local government, which is actually listed as local government expenditure, is counted as investment by state government and is distributed to lower-class roads. Units for the costs are thousands of dollars.

Length, measured in thousands of miles, is the network variable used in the study. It was not possible to acquire accurate lane-mileage estimates for all road classes.

Two output variables, annual VMT by passenger cars and VMT by trucks on each class of road, are used. Since the percentage of VMT by a vehicle type in a roadway class is not available for all 12 listed roadway classes, it needs to be estimated for those roadway classes for which it is unavailable.

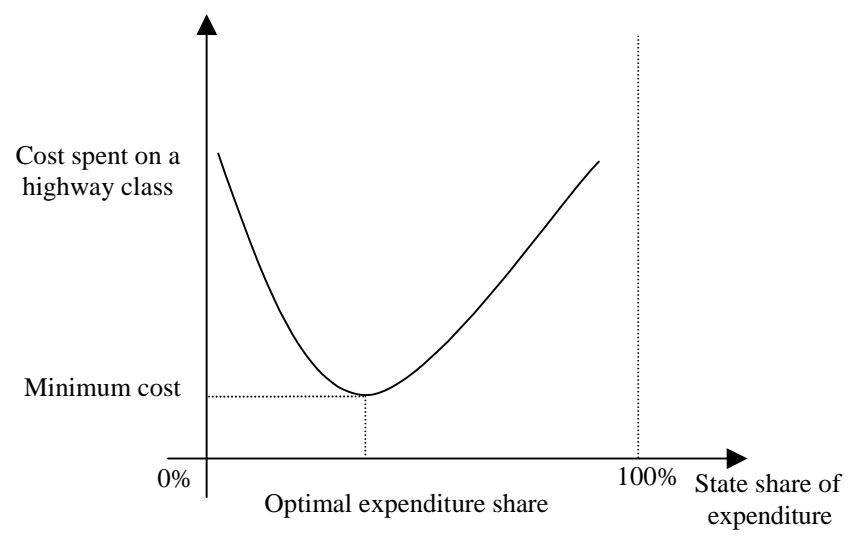

FIGURE 2 Parabolic variation of cost with respect to state's expenditure share.
For any given state, the percentage of annual VMT by a vehicle type on a roadway class is available only for the top seven roadway classes. Therefore the percentage of VMT by a vehicle type for lower roadway classes needs to be predicted. However, a model specific to a particular roadway class and generalized for all states cannot tell the percentage of VMT by a vehicle type on another roadway class. Therefore, a variable specific to position in the hierarchy is needed. Since such a variable is not readily available, an integer rank is given to each roadway class starting with 1 for urban Interstates and ending with 12 for rural local roads, at the bottom of the hierarchy of roads. This rank is used as a variable in the model. Zipf (4) related a variable or occurrence of an event and rank of that variable or event; this relationship is known as Zipf's law. That observation is extended to relate the percentage of VMT by a vehicle type on a roadway class and the rank of that roadway class in the highway hierarchy.

A model that is generalized for both roadway classes and for states is as follows:

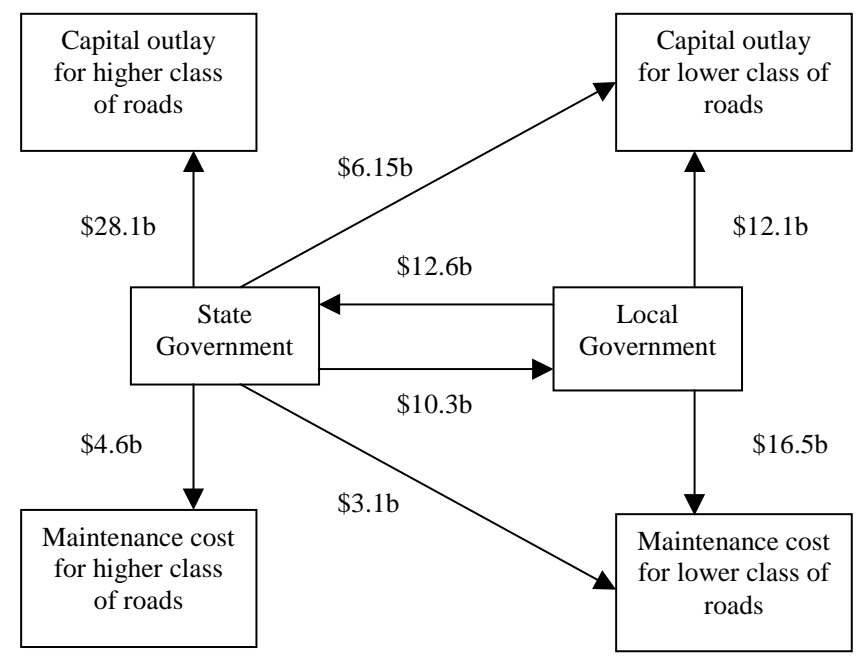

FIGURE 3 Schematic representation of money flow from state and local governments for capital outlay and maintenance costs of highway classes. 


$$
\begin{aligned}
& \hat{p}_{i z}=\delta_{p} R_{z}^{\alpha_{p}}\left(v_{i z}\right)^{\beta_{p}}\left(l_{i z}\right)^{\gamma_{p}} \\
& \hat{t}_{i z}=\delta_{t} R_{z}^{\alpha_{t}}\left(v_{i z}\right)^{\beta_{t}}\left(l_{i z}\right)^{\gamma_{t}}
\end{aligned}
$$

where

$\hat{p}_{i z}=$ estimated percentage of VMT by passenger cars in $i$ th state on $z$ th roadway class;

$\hat{t}_{i z}=$ estimated percentage of VMT by trucks in $i$ th state and on $z$ th roadway class;

$R_{z}=$ rank of $z$ th roadway class;

$v_{i z}=$ percentage of total VMT on $z$ th roadway class in $i$ th state;

$l_{i z}=$ percentage of road length of $z$ th roadway class in $i$ th state; and

$\alpha, \beta, \gamma, \delta=$ coefficients from regression, with subscript $p$ representing coefficients for model of passenger cars and subscript $t$ representing coefficients for truck model.

Since there are multiple vehicle types (passenger cars, trucks, transit buses, motorcycles, school buses, etc.), determining the percentage of annual VMT by passenger cars does not give the percentage of annual VMT by trucks. The ordinary least-squares regression results of these models are shown in Table 1 .

After prediction of the percentage of annual VMT by vehicle type for all roadway classes and for all states, these values are used in calculating the annual VMT by a vehicle type in a state on a highway class. There are two highway classes (higher and lower), an aggregation of 12 roadway classes. The annual VMT by a vehicle type in a state on a highway class is calculated as follows:

$$
\begin{aligned}
& p_{Z i}=\sum_{z \in\{Z\}} \hat{p}_{i z} V_{z} \quad Z \in\{\bar{H}, H, h\} \\
& t_{Z i}=\sum_{z \in\{Z\}} \hat{t}_{i z} V_{z} \quad Z \in\{\bar{H}, H, h\}
\end{aligned}
$$

where

$p_{Z i}=$ millions of VMT by passenger cars in $i$ th state on highway class $Z$,

$t_{Z i}=$ millions of VMT by trucks in $i$ th state on highway class $Z$,

$V_{z}=$ total VMT by all vehicle types on $z$ th class of roads,

$Z=$ set of subscripts that represent highway class,
$\bar{H}=$ subscript that represents all roads,

$H=$ subscript that represents higher highway class, and

$h=$ subscript that represents lower highway class.

For convenience, the subscript $i$ in $p_{Z i}, t_{Z i}$ has been dropped.

The mean, standard deviation, minimum value, and maximum value of the variables used in this paper are shown in Table 2.

The highways in the 50 United States and the District of Columbia are financed differently, and there is no reason to expect them to have similar expenditure shares by state and local governments. In some states like Minnesota, New Jersey, and Colorado, the local government assumes most of the expenditure on capital outlay and maintenance, whereas the state government share is less than $40 \%$ of the total expenditure. In other states like Kentucky, West Virginia, and New Mexico, the state government finances most of the expenditure on capital outlay and maintenance, and local government finances less than $20 \%$ of the total expenditure. States are arranged in ascending order of their total expenditure share in Table 3.

\section{MODEL}

Since there are three cost categories, three such models are possible for each highway class. But the relationship between the costs and expenditure shares and the relationship between the highway classes simplify the model by reducing the degrees of freedom of the problem. The relationship between the costs for any highway class is

$$
\begin{aligned}
C_{x, y, H}+C_{x, y, h}=C_{x, y, \bar{H}} \quad C_{E, y, Z}+C_{e, y, Z}= & C_{\bar{E}, y, Z} \\
& C_{x, G, Z}+C_{x, g, Z}=C_{x, \bar{G}, Z}
\end{aligned}
$$$$
x \in\{\bar{E}, E, e\} \quad y \in\{\bar{G}, G, g\} \quad Z \in\{\bar{H}, H, h\}
$$

where

$$
x=\text { type of highway cost; }
$$

$e, E, \bar{E}=$ maintenance, capital, and total costs, respectively;

$y=$ government layer;

$g, G, \bar{G}=$ local, state, and both governments, respectively; and

$C_{x, y, Z}=$ cost of type $x$ spent by government layer $y$ on highway class $Z$.

Variables in Equation 3 are shown in Table 4, in which 27 variables are defined. However, these 27 variables are linearly dependent, so

TABLE 1 Regression Results for Percentage of VMT on zth Roadway Class by Passenger Cars and Trucks

\begin{tabular}{|c|c|c|c|c|}
\hline \multirow{2}{*}{ Variable } & \multicolumn{2}{|c|}{ Passenger Cars } & \multicolumn{2}{c|}{ Trucks } \\
\cline { 2 - 5 } & Coefficient & Standard Error & Coefficient & Standard Error \\
\hline $\ln \left(\mathrm{R}_{\mathrm{z}}\right)-\alpha$ & 0.092 & 0.011 & -0.65 & 0.08 \\
\hline $\ln \left(\mathrm{v}_{\mathrm{iz}}\right)-\beta$ & 0.037 & 0.0089 & -0.28 & 0.066 \\
\hline $\ln \left(\mathrm{l}_{\mathrm{iz}}\right)-\gamma$ & -0.041 & 0.0069 & 0.28 & 0.05 \\
\hline Constant $-\delta$ & -0.337 & 0.029 & -1.011 & 0.209 \\
\hline $\begin{array}{c}\text { Number of } \\
\text { Observations }\end{array}$ & \multicolumn{2}{|c|}{300} & \multicolumn{2}{c|}{333} \\
\hline R-Squared & \multicolumn{2}{|c|}{0.20} & \multicolumn{2}{c|}{0.17} \\
\hline Adj. R-Squared & \multicolumn{2}{|c|}{0.20} & \multicolumn{2}{c|}{} \\
\hline
\end{tabular}

NotE: All variables are significant at $99 \%$ confidence interval 
TABLE 2 Summary Statistics for Variables

\begin{tabular}{|c|c|c|c|c|c|}
\hline & & Mean & $\begin{array}{r}\text { Standard } \\
\text { Deviation }\end{array}$ & Minimum & Maximum \\
\hline \multirow{3}{*}{$\begin{array}{c}\text { All Roads }(1000 \text { 's } \\
\text { of dollars) }\end{array}$} & Total Expenditure & 1621642 & 1449548 & 176065 & 6331273 \\
\hline & Capital Outlay & 1092305 & 996747 & 106972 & 4488266 \\
\hline & Maintenance & 529337 & 505670 & 51715 & 2224744 \\
\hline \multirow{3}{*}{\begin{tabular}{|} 
Higher Highway \\
Class \\
(thousands of \\
dollars)
\end{tabular}} & Total Expenditure & 752433 & 621471 & 51574 & 2589071 \\
\hline & Capital Outlay & 642177 & 556348 & 44805 & 2285781 \\
\hline & Maintenance & 110255 & 89360 & 6769 & 430575 \\
\hline \multirow{3}{*}{\begin{tabular}{|c|} 
Lower Highway \\
Class \\
(thousands of \\
dollars)
\end{tabular}} & Total Expenditure & 896545 & 882770 & 104665 & 4268101 \\
\hline & Capital Outlay & 469771 & 493886 & 62167 & 2209281 \\
\hline & Maintenance & 426774 & 442484 & 25061 & 2058820 \\
\hline \multicolumn{2}{|c|}{$\begin{array}{l}\text { Length of all roads } \\
\text { (thousands of miles) }\end{array}$} & 79918 & 51677 & 5992 & 295306 \\
\hline \multicolumn{2}{|c|}{$\begin{array}{l}\text { VMT by passenger cars on all roads } \\
\text { (million VMT) }\end{array}$} & 50765 & 50406 & 5588 & 274362 \\
\hline \multicolumn{2}{|c|}{$\begin{array}{l}\text { VMT by trucks on all roads } \\
\text { (million VMT) }\end{array}$} & 5716 & 6029 & 607 & 34148 \\
\hline
\end{tabular}

that if the right eight of them are known, the remaining cost variables can be derived.

The expenditure share of the state government layer is calculated as

$$
q_{x, Z}=\frac{C_{x, G, Z}}{C_{x, \bar{G}, Z}} \quad x \in\{\bar{E}, E, e\} \quad Z \in\{\bar{H}, H, h\}
$$

where $q_{x, Z}$ is the expenditure share of state government for cost type $x$ spent on highway class $Z$.

Since the state government expenditure share introduced in Equation 4 depends on cost variables, the number of degrees of freedom of the problem remains 8 . Therefore, if either eight independent cost values or four independent total cost variables (any four independent variables from Table 4) and the corresponding four expenditure share values are known, the system of equations can be solved.

Since the objective of the study is to find an optimal expenditure share, costs are expressed as a function of expenditure shares as

$$
C_{x, \bar{G}, Z}=f\left(q_{x, Z}, l_{Z}, p_{Z}, t_{Z}\right) \quad x \in\{\bar{E}, E, e\} \quad Z \in\{\bar{H}, H, h\}
$$

where $l_{Z}$ is the length of highways in a state on highway class $Z$ in thousands of miles.

Since the number of degrees of freedom for the problem is 8 , four versions of Equation 5 are sufficient for the analysis; five versions would be redundant.

Regression models were tested to fit an appropriate model for capital outlay and total costs for higher highway classes and all roads. The model with the best fit is a quasi-Cobb-Douglas function as follows:

$$
\begin{aligned}
& \ln \left(C_{x, \bar{G}, Z}\right)= a_{x, Z, 1} q_{x, Z}+a_{x, Z, 2} q_{x, Z}^{2}+a_{x, Z, 3} \ln \left(l_{Z}\right) \\
&+a_{x, Z, 4} \ln \left(\frac{p_{Z}}{l_{Z}}\right)+a_{x, Z, 5}\left(\frac{t_{Z}}{p_{Z}+t_{Z}}\right)+a_{x, Z, 6} \\
& x \in\{\bar{E}, E\} \quad Z \in\{\bar{H}, H\}
\end{aligned}
$$

where the $a_{x, Z, i}$ 's are coefficients.
Variables adopted in the quasi-Cobb-Douglas model (Equation 6) are not completely serendipitous. The reason for considering $(p / l)$ as a variable is to reduce the multicollinearity between VMT by passenger cars and length of roads in a state. Similarly, the $t /(p+t)$ variable is considered to reduce the multicollinearity problems between VMT by passenger cars and VMT by trucks. A model without these multicollinearity corrections gives coefficients with unacceptable signs. Outliers are tackled by taking the natural logarithm to those variables, which has a frequency distribution with considerable points in its tail.

Expenditure share and its square are considered in the model, so the model is capable of investigating an "optimal" expenditure share for a typical state, at which the cost is minimum. If the optimal expenditure share is greater than 1 , the cost is minimum when it is completely funded by state government. If the optimal value is negative, the cost is minimum when it is completely funded by local government. If the optimal is between zero and 1 , the cost should be shared between state and local governments accordingly. A cost function is convex with respect to expenditure share (i.e., the cost function is minimized) if and only if the coefficients of expenditure shares are as follows:

$a_{x, Z, 2}>0$

where $x \in\{\bar{E}, E\}, Z \in\{\bar{H}, H\}$.

\section{RESULTS AND INTERPRETATION}

\section{Optimum Expenditure Shares}

The model described above was estimated with ordinary least-squares regression. Results show that both total expenditure and capital outlay in higher and lower highway classes are convex functions with respect to expenditure shares. Therefore expenditures attain a minimum value at a particular expenditure share, which can be calculated using the coefficients of the expenditure share variables: 
TABLE 3 States in Ascending Order of State Government Expenditure Share

\begin{tabular}{|c|c|c|c|}
\hline State & $\begin{array}{c}\text { Total Expenditure } \\
(1000 \text { 's of } \$)\end{array}$ & $\begin{array}{c}\text { Total State Government } \\
\text { Expenditure }(1000 \text { 's of \$) }\end{array}$ & $\begin{array}{l}\text { State Expenditure } \\
\text { Share } \\
\end{array}$ \\
\hline New York & 6331273 & 2689839 & 0.425 \\
\hline New Jersey & 1991851 & 1029651 & 0.517 \\
\hline California & 5938095 & 3089928 & 0.520 \\
\hline Wisconsin & 1631278 & 858066 & 0.526 \\
\hline Minnesota & 1843735 & 984290 & 0.534 \\
\hline Colorado & 1312489 & 706665 & 0.538 \\
\hline Georgia & 2320575 & 1254391 & 0.541 \\
\hline New Hampshire & 361749 & 209581 & 0.579 \\
\hline Washington & 1663352 & 967818 & 0.582 \\
\hline Nebraska & 864951 & 512047 & 0.592 \\
\hline Texas & 5334564 & 3272742 & 0.613 \\
\hline Michigan & 1798957 & 1145470 & 0.637 \\
\hline Florida & 4028253 & 2572354 & 0.639 \\
\hline Vermont & 176065 & 113954 & 0.647 \\
\hline Arizona & 1047274 & 679614 & 0.649 \\
\hline Ohio & 2932548 & 1933972 & 0.659 \\
\hline South Dakota & 351819 & 237326 & 0.675 \\
\hline Pennsylvania & 2868794 & 1986201 & 0.692 \\
\hline Utah & 527795 & 369830 & 0.701 \\
\hline Missouri & 1748990 & 1234866 & 0.706 \\
\hline Alabama & 1295225 & 922734 & 0.712 \\
\hline Massachusetts & 2354514 & 1681030 & 0.714 \\
\hline Mississippi & 860182 & 616542 & 0.717 \\
\hline Virginia & 2242416 & 1637130 & 0.730 \\
\hline Maryland & 1202163 & 884223 & 0.736 \\
\hline Louisiana & 892840 & 658139 & 0.737 \\
\hline Maine & 489024 & 361268 & 0.739 \\
\hline Illinois & 2732796 & 2021191 & 0.740 \\
\hline Kansas & 1131432 & 839875 & 0.742 \\
\hline Wyoming & 322515 & 244777 & 0.759 \\
\hline Connecticut & 805205 & 612964 & 0.761 \\
\hline Oklahoma & 810144 & 623847 & 0.770 \\
\hline Oregon & 924466 & 740186 & 0.801 \\
\hline Tennessee & 1261991 & 1026792 & 0.814 \\
\hline Arkansas & 772453 & 635185 & 0.822 \\
\hline South Carolina & 650440 & 546440 & 0.840 \\
\hline Nevada & 395445 & 338974 & 0.857 \\
\hline North Carolina & 1709250 & 1491937 & 0.873 \\
\hline Indiana & 1322573 & 1154715 & 0.873 \\
\hline Rhode Island & 227626 & 200068 & 0.879 \\
\hline New Mexico & 409915 & 368086 & 0.898 \\
\hline West Virginia & 822749 & 776569 & 0.944 \\
\hline Kentucky & 1020850 & 993315 & 0.973 \\
\hline
\end{tabular}

NoтE: Only 43 states used in the analysis are listed here. Other states were dropped from the analysis because of unavailability of volume data.

TABLE 4 Explanation of Variables in Equation 3

\begin{tabular}{|c|c|c|c|c|}
\hline & & $\begin{array}{l}\text { Higher Highway } \\
\text { Class }\end{array}$ & $\begin{array}{c}\text { Lower Highway } \\
\text { Class }\end{array}$ & All Roads \\
\hline \multirow{3}{*}{$\begin{array}{l}\text { Capital } \\
\text { Outlay }\end{array}$} & $\begin{array}{c}\text { State } \\
\text { Government }\end{array}$ & $C_{E, G, H}$ & $C_{E, G, h}$ & $C_{E, G, \bar{H}}$ \\
\hline & $\begin{array}{c}\text { Local } \\
\text { Government }\end{array}$ & $C_{E, g, H}$ & $C_{E, g, h}$ & $C_{E, g, \bar{H}}$ \\
\hline & Total & $C_{E, \bar{G}, H}$ & $C_{E, \bar{G}, h}$ & $C_{E, \bar{G}, \bar{H}}$ \\
\hline \multirow{3}{*}{ Maintenance } & $\begin{array}{c}\text { State } \\
\text { Government }\end{array}$ & $C_{e, G, H}$ & $C_{e, G, h}$ & $C_{e, G, \bar{H}}$ \\
\hline & $\begin{array}{c}\text { Local } \\
\text { Government }\end{array}$ & $C_{e, g, H}$ & $C_{e, g, h}$ & $C_{e, g, \bar{H}}$ \\
\hline & Total & $C_{e, \bar{G}, H}$ & $C_{e, \bar{G}, h}$ & $C_{e, \bar{G}, \bar{H}}$ \\
\hline \multirow{3}{*}{$\begin{array}{c}\text { Total } \\
\text { Expenditure }\end{array}$} & $\begin{array}{c}\text { State } \\
\text { Government }\end{array}$ & $C_{\bar{E}, G, H}$ & $C_{\bar{E}, G, h}$ & $C_{\bar{E}, G, \bar{H}}$ \\
\hline & $\begin{array}{c}\text { Local } \\
\text { Government }\end{array}$ & $C_{\bar{E}, g, H}$ & $C_{\bar{E}, g, h}$ & $C_{\bar{E}, g, \bar{H}}$ \\
\hline & Total & $C_{\bar{E}, \bar{G}, H}$ & $C_{\bar{E}, \bar{G}, h}$ & $C_{\bar{E}, \bar{G}, \bar{H}}$ \\
\hline
\end{tabular}


TABLE 5 Regression Results for Total Expenditure and Capital Outlay on All Roads

\begin{tabular}{|c|c|c|c|c|c|c|c|c|}
\hline \multirow[b]{2}{*}{ Variable } & \multicolumn{4}{|c|}{ Total Expenditure } & \multicolumn{4}{|c|}{ Capital Outlay } \\
\hline & & $\begin{array}{l}\text { Coef- } \\
\text { ficient }\end{array}$ & $\begin{array}{l}\text { Standard } \\
\text { Error }\end{array}$ & $\begin{array}{c}\mathrm{P}- \\
\text { value }\end{array}$ & & $\begin{array}{l}\text { Coef- } \\
\text { ficient }\end{array}$ & \begin{tabular}{|c|} 
Standard \\
Error
\end{tabular} & $\begin{array}{c}\mathrm{P}- \\
\text { value }\end{array}$ \\
\hline Expenditure share & $a_{\bar{E}, \bar{H}, 1}$ & -5.62 & 2.84 & 0.055 & $a_{E, \bar{H}, 1}$ & -9.13 & 3.84 & 0.023 \\
\hline $\begin{array}{c}\text { Square of } \\
\text { expenditure share } \\
\text { by state } \\
\text { government }\end{array}$ & $a_{\bar{E}, \bar{H}, 2}$ & 3.2 & 1.98 & 0.115 & $a_{E, \bar{H}, 2}$ & 5.20 & 2.53 & 0.047 \\
\hline $\begin{array}{l}\text { Natural logarithm } \\
\text { of length }\end{array}$ & $a_{\bar{E}, \bar{H}, 3}$ & 0.90 & 0.06 & 0.000 & $a_{E, \bar{H}, 3}$ & 0.89 & 0.07 & 0.000 \\
\hline $\begin{array}{c}\text { Natural logarithm } \\
\text { of (VMT by } \\
\text { passenger } \\
\text { cars/length) } \\
\end{array}$ & $a_{\bar{E}, \bar{H}, 4}$ & 0.63 & 0.11 & 0.000 & $a_{E, \bar{H}, 4}$ & 0.60 & 0.12 & 0.000 \\
\hline $\begin{array}{c}\text { Fraction of VMT } \\
\text { by trucks }\end{array}$ & $a_{\bar{E}, \bar{H}, 5}$ & 16.15 & 8.89 & 0.077 & $a_{E, \bar{H}, 5}$ & 18.19 & 9.80 & 0.071 \\
\hline Constant & $a_{\bar{E}, \bar{H}, 6}$ & 5.08 & 1.49 & 0.002 & $a_{E, \bar{H}, 6}$ & 6.20 & 1.85 & 0.002 \\
\hline $\begin{array}{c}\text { No. of } \\
\text { observations }\end{array}$ & \multicolumn{4}{|c|}{43} & \multicolumn{4}{|c|}{43} \\
\hline R-squared & \multicolumn{4}{|c|}{0.93} & \multicolumn{4}{|c|}{0.92} \\
\hline Adj. R-squared & \multicolumn{4}{|c|}{0.92} & \multicolumn{4}{|c|}{0.90} \\
\hline
\end{tabular}

$q_{x, Z}^{*}=\frac{-a_{x, Z, 1}}{2 a_{x, Z, 2}} \quad x \in\{\bar{E}, E\} \quad Z \in\{\bar{H}, H\}$

where $q_{x, Z}^{*}$ represents the optimal expenditure share of the state government for cost type $x$ on highway class $Z$.

The regression results for total costs and capital outlay for all roads are shown in Table 5 and those for the higher highway class in Table 6.

Using Equations 6 and 8, the minimum value of $C_{x, \bar{G}, Z}$, represented by $C_{x, \bar{G}, Z}^{*}$, can be calculated for $x \in\{\bar{E}, E\}, Z \in\{\bar{H}, H\}$, and $q_{e, Z}^{*}$, the optimal value of maintenance cost for highway class $Z \epsilon\{\bar{H}, H\}$, can be calculated by

$$
q_{e, Z}^{*}=\frac{C_{\bar{E}, \bar{G}, Z}^{*} q_{\bar{E}, Z}^{*}-C_{E, \bar{G}, Z}^{*} q_{E, Z}^{*}}{C_{\bar{E}, \bar{G}, Z}^{*}-C_{E, \bar{G}, Z}^{*}} \quad Z \in\{\bar{H}, H\}
$$

The calculated maintenance cost is optimal, but the maintenance share by state government calculated using Equation 9 might not be optimal.

TABLE 6 Regression Results for Total Expenditure and Capital Outlay on Higher Highway Class

\begin{tabular}{|c|c|c|c|c|c|c|c|c|}
\hline \multirow[b]{2}{*}{ Variable } & \multicolumn{4}{|c|}{ Total Expenditure } & \multicolumn{4}{|c|}{ Capital Outlay } \\
\hline & & $\begin{array}{l}\text { Coef- } \\
\text { ficient }\end{array}$ & \begin{tabular}{|c} 
Standard \\
Error
\end{tabular} & $\begin{array}{c}\mathrm{P}- \\
\text { value }\end{array}$ & & $\begin{array}{l}\text { Coef- } \\
\text { ficient }\end{array}$ & $\begin{array}{l}\text { Standard } \\
\text { Error }\end{array}$ & $\begin{array}{c}\mathrm{P}- \\
\text { value }\end{array}$ \\
\hline Expenditure share & $a_{\bar{E}, H, 1}$ & -1178 & 326 & 0.001 & $a_{E, H, 1}$ & -1405 & 372 & 0.001 \\
\hline $\begin{array}{c}\text { Square of } \\
\text { expenditure share } \\
\text { by state } \\
\text { government }\end{array}$ & $a_{\bar{E}, H, 2}$ & 603 & 167 & 0.001 & $a_{E, H, 2}$ & 718 & 19 & 0.001 \\
\hline $\begin{array}{l}\text { Natural logarithm } \\
\text { of length }\end{array}$ & $a_{\bar{E}, H, 3}$ & 1.03 & 0.07 & 0.000 & $a_{E, H, 3}$ & 1.04 & 0.08 & 0.000 \\
\hline $\begin{array}{c}\text { Natural logarithm } \\
\text { of (VMT by } \\
\text { passenger } \\
\text { cars/length) } \\
\end{array}$ & $a_{\bar{E}, H, 4}$ & 0.67 & 0.12 & 0.000 & $a_{E, H, 4}$ & 0.71 & 0.14 & 0.000 \\
\hline $\begin{array}{c}\text { Fraction of VMT } \\
\text { by trucks }\end{array}$ & $a_{\bar{E}, H, 5}$ & 14.63 & 6.89 & 0.042 & $a_{E, H, 5}$ & 13.08 & 7.87 & 0.089 \\
\hline Constant & $a_{\bar{E}, H, 6}$ & 577 & 159 & 0.001 & $a_{E, H, 6}$ & 688 & 181 & 0.001 \\
\hline $\begin{array}{c}\text { No. of } \\
\text { observations }\end{array}$ & \multicolumn{4}{|c|}{38} & \multicolumn{4}{|c|}{38} \\
\hline R-squared & \multicolumn{4}{|c|}{0.92} & \multicolumn{4}{|c|}{0.90} \\
\hline Adj. R-squared & \multicolumn{4}{|c|}{0.91} & \multicolumn{4}{|c|}{0.89} \\
\hline
\end{tabular}


The quantities $q_{x, Z}^{*}$ for $x \in\{\bar{E}, E\}$ and $Z \epsilon\{\bar{H}, H\}$ depend only on regression coefficients and therefore are the same for every state. But $q_{e, Z}^{*}$ for $Z \epsilon\{\bar{H}, H\}$ depends on $C_{x, \bar{G}, Z}^{*}$, which is specific to each state; therefore $q_{e, Z}^{*}$ is computed for each state separately, from which the average value of $q_{e, Z}^{*}$ is calculated.

So far, the optimal expenditure and optimal expenditure shares are calculated only for the higher highway class and the all-roads case. Using the results obtained from these calculations, the optimal expenditure and optimal expenditure share for state government for the lower highway class can be calculated.

$$
\begin{aligned}
& C_{x, \bar{G}, h}^{*}=C_{x, \bar{G}, \bar{H}}^{*}-C_{x, \bar{G}, H}^{*} \\
& q_{x, h}^{*}=\frac{C_{x, \bar{G}, \bar{H}}^{*} q_{x, \bar{H}}^{*}-C_{x, \bar{G}, H}^{*} q_{x, H}^{*}}{C_{x, \bar{G}, H}^{*}} \quad x \in\{\bar{E}, E, e\}
\end{aligned}
$$

The optimum expenditure shares obtained using Equations 8, 9, and 10 are stochastic in nature. The values of these optimums, given in Table 7, are calculated by using the mean values of the coefficients of Equation 6 and are compared with the mean shares.

The results show that state government, in order to minimize costs, should increase its share of investment in lower-class roads. Economies of scale can be utilized to reduce the costs on lower-class roads. States have certain advantages in funding roads like centralized administration and centralized purchasing of equipment and raw materials. But state government alone cannot attend to the needs of investment demands for roads. The trade-off between economies of scale achieved by the state government and detailed community knowledge available to local governments results in an optimal mix of state government and local government funding.

\section{Marginal Costs and Elasticities}

Using the total expenditure and capital outlay functions (Equation 6), marginal cost functions can be calculated for each type of vehicle (passenger cars and trucks) on each highway class as follows:

$$
\begin{gathered}
\frac{\partial C_{x, \bar{G}, Z}}{\partial p_{Z}}=C_{x, \bar{G}, Z}\left\{\frac{a_{x, Z, 4}}{p_{Z}}+a_{x, Z, 5}\left[\frac{\partial t_{Z}}{\partial p_{Z}} \frac{p_{Z}}{\left(p_{Z}+t_{Z}\right)^{2}}-\frac{t_{Z}}{\left(p_{Z}+t_{Z}\right)^{2}}\right]\right\} \\
x \in\{\bar{E}, E\} \quad Z \in\{\bar{H}, H\} \\
\frac{\partial C_{x, \bar{G}, Z}}{\partial t_{Z}}=C_{x, \bar{G}, Z}\left[\frac{a_{x, Z, 4}}{p_{Z}} \frac{\partial p_{Z}}{\partial t_{Z}}+\frac{a_{x, Z, 5}}{\left(p_{Z}+t_{Z}\right)^{2}}\left(p_{Z}-t_{Z} \frac{\partial p_{Z}}{\partial t_{Z}}\right)\right] \\
x \in\{\bar{E}, E\} \quad Z \in\{\bar{H}, H\} \quad(11)
\end{gathered}
$$

TABLE 7 Optimal Expenditure Share of State Government Compared with Mean Values of State Government Expenditure Share

\begin{tabular}{|c|c|c|c|c|}
\hline \multicolumn{2}{|c|}{} & $\begin{array}{c}\text { Higher } \\
\text { Roads }\end{array}$ & $\begin{array}{c}\text { Lower } \\
\text { Roads }\end{array}$ & All Roads \\
\hline \multirow{2}{*}{$\begin{array}{c}\text { Capital } \\
\text { outlay }\end{array}$} & Mean & 0.983 & 0.567 & 0.800 \\
\cline { 2 - 5 } & Optimal & 0.977 & 0.741 & 0.877 \\
\hline \multirow{3}{*}{ Maintenance } & Mean & 0.988 & 0.390 & 0.524 \\
\cline { 2 - 5 } & Optimal & 0.975 & 0.843 & 0.881 \\
\hline \multirow{2}{*}{ Total costs } & Mean & 0.984 & 0.479 & 0.707 \\
\cline { 2 - 5 } & Optimal & 0.977 & 0.790 & 0.8781 \\
\hline
\end{tabular}

where $\partial C_{x, \bar{G}, Z} / \partial p_{Z}$ represents the marginal cost for cost type $x$ on highway class $Z$ with respect to VMT by passenger cars on that highway class and $\partial C_{x, \bar{G}, Z} / \partial t_{Z}$ represents the marginal cost for cost type $x$ on highway class $Z$ with respect to VMT by trucks on that class.

Cost elasticities for total expenditure and capital outlay for annual VMT by passenger cars and trucks can be obtained by using Equations 11. Elasticity functions $(\eta)$ are as follows:

$$
\begin{gathered}
\eta_{x, Z, p}=\frac{\frac{\partial C_{x, \bar{G}, Z}}{\partial p_{Z}}}{\frac{C_{x, \bar{G}, Z}}{p_{Z}}} \quad x \in\{\bar{E}, E\} \quad Z \in\{\bar{H}, H\} \\
\eta_{x, Z, t}=\frac{\frac{\partial C_{x, \bar{G}, Z}}{\partial t_{Z}}}{\frac{C_{x, \bar{G}, Z}}{t_{Z}}} \quad x \in\{\bar{E}, E\} \quad Z \in\{\bar{H}, H\}
\end{gathered}
$$

The marginal costs and elasticities of maintenance costs for the higher highway class and for all roads can be calculated using the values from Equations 11 as follows:

$$
\begin{aligned}
& \frac{\partial C_{e, \bar{G}, Z}}{\partial p_{Z}}=\frac{\partial C_{\bar{E}, \bar{G}, Z}}{\partial p_{Z}}-\frac{\partial C_{E, \bar{G}, Z}}{\partial p_{Z}} \quad \frac{\partial C_{e, \bar{G}, Z}}{\partial t_{Z}}=\frac{\partial C_{\bar{E}, \bar{G}, Z}}{\partial t_{Z}}-\frac{\partial C_{E, \bar{G}, Z}}{\partial t_{Z}} \\
& Z \in\{\bar{H}, H\} \\
& \eta_{e, Z, p}=\frac{\frac{\partial C_{e, \bar{G}, Z}}{\frac{\partial p_{Z}}{C_{e, \bar{G}, Z}}}}{p_{Z}} \quad \eta_{e, Z, t}=\frac{\frac{\partial C_{e, \bar{G}, Z}}{\partial t_{Z}}}{\frac{C_{e, \bar{G}, Z}}{t_{Z}}} \quad Z \in\{\bar{H}, H\}
\end{aligned}
$$

The elasticities for the lower highway class are calculated using the following marginal costs for the lower highway class:

$$
\begin{gathered}
\frac{\partial C_{x, \bar{G}, h}}{\partial p_{h}}=\frac{\partial C_{x, \bar{G}, Z}}{\partial p_{\bar{H}}} \frac{\partial p_{\bar{H}}}{\partial p_{h}}-\frac{\partial C_{x, \bar{G}, H}}{\partial p_{H}} \frac{\partial p_{H}}{\partial p_{h}} \quad x \in\{\bar{E}, E\} \\
\frac{\partial C_{x, \bar{G}, h}}{\partial t_{h}}=\frac{\partial C_{x, \bar{G}, \bar{H}}}{\partial t_{\bar{H}}} \frac{\partial t_{\bar{H}}}{\partial t_{h}}-\frac{\partial C_{x, \bar{G}, H}}{\partial t_{H}} \frac{\partial t_{H}}{\partial t_{h}} \quad x \in\{\bar{E}, E\}
\end{gathered}
$$

The elasticities of total expenditure, maintenance costs, and capital outlay for passenger cars and trucks on the higher highway class, the lower highway class, and all roads are shown in Table 8.

It is found that highway costs are relatively inelastic with respect to passenger cars and trucks on all highway classes. That is, a $1 \%$ increase in VMT by passenger cars or trucks will cause less than a percent increase in highway costs. Since economy of scale is the reciprocal of elasticity, passenger cars and trucks have increasing economies of scale.

Note that economies of scale for trucks obtained in this study are similar to the economies of scale obtained by Levinson and Gillen (3), whereas the economies of scale for passenger cars are different from their results. This finding is due to different variables considered in these studies. Levinson and Gillen adopted the price of labor and bond interest as variables, and length of roads is not considered in their model.

\section{CONCLUSIONS AND RECOMMENDATIONS}

A model was developed that explains highway capital and maintenance costs with respect to expenditure share by state and local governments on higher and lower road classes. This research investigated 
TABLE 8 Economies of Scale for Highway Costs with Respect to Passenger Cars and Trucks

\begin{tabular}{|c|c|c|c|c|c|c|}
\hline \multirow{2}{*}{} & \multicolumn{2}{|c|}{ Higher Highway Class } & \multicolumn{2}{c|}{ Lower Highway Class } & \multicolumn{2}{c|}{ All Roads } \\
\cline { 2 - 7 } & $\begin{array}{c}\text { Passenger } \\
\text { Cars }\end{array}$ & Trucks & $\begin{array}{c}\text { Passenger } \\
\text { Cars }\end{array}$ & Trucks & $\begin{array}{c}\text { Passenger } \\
\text { Cars }\end{array}$ & Trucks \\
\hline $\begin{array}{c}\text { Capital } \\
\text { outlay }\end{array}$ & 0.839 & 0.749 & 0.564 & 0.545 & 0.731 & 0.671 \\
\hline Maintenance & 0.564 & 0.493 & 0.928 & 0.936 & 0.795 & 0.730 \\
\hline \begin{tabular}{c} 
Total costs \\
\hline $\begin{array}{c}\text { Economies } \\
\text { of scale }\end{array}$
\end{tabular} & 0.803 & 0.716 & 0.742 & 0.736 & 0.749 & 0.687 \\
\hline
\end{tabular}

the existence of a minimal highway cost when the share of expenditure between state and local governments is varied. These parabolic models attain a minimum expenditure share. These highway cost functions can be used in formulating policies that minimize highway costs. It was found that a shift in highway financial responsibilities between different government layers, particularly if the states take on a greater responsibility for lower-class roads from local governments, can reduce highway costs.

The total amount of money spent for capital outlay and maintenance on all the roads in the United States in 1996 is more than $\$ 69$ billion. This research showed that if in every state the expenditure on the roads is shared between state and local governments using the optimal share computed from the model, all states together can save more than $\$ 13$ billion, which is almost $19 \%$ of the total cost. Of this $\$ 13$ billion, $60 \%$ of the savings are obtained by reorganizing the expenditure share between state and local governments on capital outlay.

For research problems like this, statistical techniques like frontier analysis can be adopted to model the inefficiencies involved; further research in this direction can help in better understanding the effect of hierarchical investment on highway cost efficiencies. This study makes no distinction based on quality of service; additional research could shed light on the effect of the highway investment pattern between state and local governments on the quality of roads.

\section{REFERENCES}

1. McShane, W. R., and R. R. Roess. Traffic Engineering. Prentice Hall, Englewood Cliffs, N.J., 1990.

2. 1996 Highway Statistics. FHWA, U.S. Department of Transportation. www.fhwa.dot.gov/ohim/1996/index.html. Accessed Oct. 26, 2000.

3. Levinson, D. M., and D. Gillen. The Full Cost of Intercity Highway Transportation. Transportation Research, Vol. 34D, 1998, pp. 207-223.

4. Zipf, G. K. Selective Studies and the Principle of Relative Frequency in Language. Harvard University Press, Cambridge, Mass., 1931.

Publication of this paper sponsored by Committee on Taxation and Finance. 